Article

\title{
Relational Urbanisation, Resilience, Revolution: Beirut as a Relational City?
}

\author{
Michael Rafferty \\ Department of Geography and Spatial Planning, University of Luxembourg, Luxembourg; michael.rafferty@uni.lu
}

Submitted: 6 August 2021 | Accepted: 24 January 2022 | Published: 23 February 2022

\begin{abstract}
The destruction of Beirut's port and large areas of the inner city following the August 2020 explosion occurred amid (and has exacerbated) an unprecedented national economic and social crisis portending another potential phase of urban "reconstruction" and a national political revolution. Critical scholars have highlighted the shortcomings of urban planning and governance in the city after the Lebanese civil war, particularly in terms of housing, infrastructure, and social inequalities, especially between the urban core and periphery. Beirut's post-war reconstruction(s), guided by blended-scale governance (i.e., public/private, confessional/political, national/local) and a real estate-oriented growth model have neither managed to completely restore nor efface the city's erstwhile status as an entrepôt of regional and international economic, cultural, and political importance but have instigated processes of rapid urbanisation and uneven development. These processes, historical trajectories, political and socio-economic dialectics, and shifts in urban political economy render Beirut relevant to the nascent empirical category of "relational cities," i.e., cities whose geographical-historical profiles position them as urban nodes connecting regional-global-national systems of flows under globalised capitalism. This article positions Beirut in the context of the debate on relational urbanisation for empirical exploration, and also points to the evental possibilities for alternative geographies that flow from the October 2019 protests.
\end{abstract}

\section{Keywords}

Beirut; global cities; relational cities; relational urbanisation; resilience

\section{Issue}

This article is part of the issue "Urbanisation, Crisis, and Resilience: The Multiple Dimensions of Urban Transformation in Beirut, Lebanon" edited by Liliane Buccianti-Barakat (Saint Joseph University) and Markus Hesse (University of Luxembourg).

(C) 2022 by the author(s); licensee Cogitatio (Lisbon, Portugal). This article is licensed under a Creative Commons Attribution 4.0 International License (CC BY).

\section{Introduction}

This is the trouble with the Lebanese. The [reason the] Lebanese people are so inventive and so adaptable is that they adapt to situations, they make the best of a bad situation in fact. This is why they never could do a revolution, we should have done a revolution many years ago here. The people should rise up against their governors...but unfortunately...even the young Lebanese people are very traditional in their thinking. They only elect the same people, the same families, the same feudal lords and so on. (Roderick Sursock Cochrane on The Beirut Banyan, October 2019)
The recent urban history of Lebanon and its primate capital city, Beirut, is punctuated by both endogenous and exogenous events overlaying an unrelenting shift in the control of processes of urbanisation and urban planning from public to private hands. What distinguishes the protests in October 2019 in several Lebanese cities, centred on Beirut's Martyrs' Square as a reclaimed public space, from previous Lebanese political events is that they reflected less a specific, singular occurrence, and more a "general crisis of the State" (Gramsci, 1971, p. 210) reflecting discontent with the post-war settlement.

This is evident from the quoted statement, a call for revolt against Lebanon's ruling class from an unlikely 
source, the heir of Sursock Palace in Acrafieh, Beirut, which at that time of recording was the residence of a celebrated personification of the positionality of the city's international bourgeoisie held before the Lebanese civil war. Lady Yvonne Cochrane Sursock, Roderick Sursock's mother, was one of more than 200 people killed as a result of the 4 August 2020 explosion in Beirut Port, succumbing to injuries received in the palace in which she had lived for the entirety of the Lebanese civil war (Jansen, 2020).

International media and academic indexes for fragile states have increasingly described Lebanon as a failing state, or a failed state in the making (The Economist, 2021). The available economic and social evidence seems on one hand to corroborate such a position: a third of the population in extreme poverty, with blackouts affecting telecommunications and hospitals arising from non-payment of energy production fuel bills, a chronic devaluation of the Lebanese pound, and dearth of incoming dollars to underwrite expenditures. Meanwhile the Panama Papers contemporaneously reveal large extractions of capital to offshore tax-havens by members of the Lebanese ruling class. Yet, on the other hand, these extreme conditions have not yet posed any direct threat to the ruling class as constituted in the centralised sectarian-confessional national system of government (Salloukh, 2019). While the present iteration of the Lebanese state is regarded as having failed its 4.2 million citizens and 6.8 million residents, the notion of a "failed state" remains something of a misnomer until the erosion of the state's authority reaches a stage well-beyond the present atrophy. The pragmatic reality for the Lebanese ruling class is that their strange resilience rests on the continued agreement, entre eux, of a collective monopoly of centralised, shared power with the capacity to operate as a "weak state" (Fregonese, 2012) interfacing with the international institutions and interests which prefer its continued control of Lebanon to any of the envisaged alternatives.

As one of the world's most urbanised nation-states, and arguably one of the most administratively centralised, the social scientific literature on Beirut necessarily foregrounds the urban across several disciplines. As with other relational cities, the mode of urban planning has been a central, transversal factor of the development pattern and political economy of the state (Akar, 2018). For Beirut, this has been as true from the first public masterplans under Michel Écochard in the 1940s at the end of the French colonial mandate to the developerled ad-hoc development following the development of the Solidere district. The mass exodus of Beirut residents during the civil war from the inner city to the suburbs intensified after the war ended, when the political economy of the country turned towards financialisation of real estate the mode and role of urban planning shifted accordingly to become purely a facilitator for private development. Urban planning practices often described as "unplanned" development is more accu- rately described as a mode of governmentality in which developers and the local and national state operate at "blended scales" to facilitate ad-hoc suburban developments at the same time as speculative inner-city projects, without commensurate consideration for infrastructure, utilities, and transport planning (Verdeil, 2005).

This article argues that this moment of strange resilience, in preparation for national elections in May 2022, is more usefully regarded in Gramscian terms as an organic crisis of the Lebanese state, permitting the protests which started in October 2019 to be tentatively regarded as having an evental wake (Badiou, 2007) capable of producing a rupture with the present governance paradigm, producing terrain for reflection on possible alternatives. It is argued that such alternatives are imaginable via a consideration of Beirut's urbanisation through a relational lens, that is, seeing the city as being constituted and produced through relations and flows (material, capital, social, informational, cultural) from the local to the global levels, which can then be used in tandem with territorially-embedded urban perspectives towards developing alternative trajectories. As such, Beirut will be considered conceptually as a "relational city," and the relevant aspects of the relational urbanisation attendant to such a description will be identified as areas for future empirical study.

\section{Beirut in Urban Literature}

Looking beyond the modern era, the history of Berytus, the ancient city on the site of the modern Beirut, was that of a Roman and Byzantine settlement rendered as "the jewel of Phoenicia" owing to its maritime importance as a base for the Roman fleet in the Eastern Mediterranean, as well as a centre for the codification of laws under the Justinian law school (Jidejian, 1973).

In Beirut a case in point emerges prima facie in the sense of the city(-state) being constituted in the 19th century as a relational confluence of regional migration flows and maritime trade which acted as a magnet for commercial and financial activity, which in turn led to the foundation of academic and cultural institutions of international significance. With the bringing into existence of the Lebanese state, this gave Beirut an additional role as a capital city of a small postcolonial state and an increased prominence as a maritime hub following the Suez crisis. Urbanisation continued apace, mainly along the coast to the north and south of Beirut, before and during the 1975-1990 civil war and the subsequent postmodern reconstruction of the inner city connected with the neoliberal turn towards financialised real-estate urban growth. This reversed the previous modernist designs of Michel Écochard aimed at integrated, planned suburban growth.. This development pattern was by no means unique among cities in the Arab world (Verdeil, 2018), and the urban planning principles in play comported to a large degree with other (arguably relational) urbanisations which have been hitherto described in the 
literature as "spectacular cities" (Koch, 2018) owing to the particular fabric of their transformations. Essentially, the historical constitution and profile of Beirut has been primarily relational, the legacy of colonialism in the region limiting the industrial development and capitalisation of Lebanon while several prolonged phases of related migrations flowed into, and out of, Beirut from the second half of the 19th century to the present day.

Lebanon has, since its emergence as a distinct colonial state in 1920, and an independent republic in 1943, undergone an enormous process of urbanisation, the vast majority of which has occurred in what is now somewhat nebulously referred to as "Greater Beirut" (Khuri, 1975). From the basis of a town which in 1840 had around 16,000 inhabitants, Beirut became a regional entrepôt in the course of the 19th century, developing an international footprint with the establishment of several universities in the city, including two American universities from the 1860s onwards (Kassir, 2011). The greater city until 2019 represented approximately a half of the country's 4.2 million population, based on an economy which is $80 \%$ service sector led by banking (against a national picture of $60 \%$ service industry) having exponentially sprawled out into the surrounding Mount Lebanon region in the course of the $20^{\text {th }}$ century. While the city's population saw a significant reduction during the 15-year civil war from 1975-1990, urbanisation occurred on the periphery and the greater city has recently exceeded its height at the start of the conflict.

Temporally, city profiles of Beirut (Hanssen, 2005; Khalaf \& Kongstad, 1973; Krijnen, 2016; Tabet, 1991; Yassin, 2012; Zaarour \& Voiron-Canicio, 2020) present a wildly varying picture of a city undergoing a complex and relatively rapid urbanisation process in the midst of civil war, an epicentre of a turbulent and interdependent (inter)national geopolitical context, and most recently following a radically problematic neoliberal post-conflict inner-city transformation. Rapid change occurs in parallel with old sectarian certitudes and the resulting paradoxes of uneven development mushroom in scale as the city is estimated to now have above 2 million population (the last census was in 1932). This makes for an extremely rich empirical footprint in the social sciences extensively covering the city's role in Lebanon's intricate consociational (that is, mandatory, sectarian, power-sharing) system of national government, the neoliberal urbanism of the private-capital driven reconstruction of the city and its social effect, and Lebanon's unique "in-between" geopolitical and cultural position crystallised by the porous divisions of its capital city.

Beirut's impact on the Lebanese national economy is currently at its historic height, driving most of the national GDP growth in the post conflict period with an initial peak following the first materialisation of reconstruction in the late 1990s. Since 2000, GDP has more than doubled, at $\$ 52$ billion, or $\$ 8,532$ per capita in 2017. Currently, however, the country's sovereign debt is among the highest of any in the world, and a recent downturn in USD in-flows triggered a foreign cash crisis in the country which has spiralled into hyperinflation for the Lebanese Lira. Foreign in-flows have long been a specific feature of the Lebanese economy reflecting the size of Lebanon's western and Gulf diaspora and its capacity to send remittances to family members still in the country (this accounted for more than $30 \%$ of USD in the Lebanese economy in 2019), but it more worryingly portends a property-finance and affordability crisis where heightened rents and urban land prices cannot be serviced by domestic production.

While the threat of austerity measures and tax increases on consumption were the short-term causes of the 2019 protests, deeper causes reflect a long-term dissatisfaction with the post-war readjusted sectarian system of national government, centred in Beirut, members of which are domestically regarded as having benefited lucratively from the reconstruction boom while inequalities soar, particularly on Beirut's periphery.

The urbanisation of Beirut is best understood in five phases (Yassin, 2012), with a nascent sixth stage emerging since about 2017, and open to radical reorientation:

Phase 1 (1850-1920): The growth of cosmopolitan Beirut as a gateway to the Levant;

Phase 2 (1920-1958): The French mandate, early independence, and "building" a mini-Paris;

Phase 3 (1958-1975): Rapid urbanisation, urban sprawl, and the misery belt;

Phase 4 (1975-1990): Violent urbanisation and civil war;

Phase 5 (1991-2016?): Post-war reconstruction and neoliberal peace.

Some recent empirical observations (Fawaz, 2014; Krijnen, 2016; Naeff, 2017) portend a sixth phase emanating from a tangential expansion of the financeproperty economy in the city as a function of the financialisation of housing globally, resulting in a new revanchism (Smith, 2005) protruding outwards from the city and prioritisation of the maintenance of urban inequalities between the city's rich inner core and persistently impoverished outer periphery.

The most recent urban transformation of Beirut is usually framed around Lebanon's encounter with neoliberalism following the changing geopolitical scenery from 1990 onwards in the Middle East and in the national context of the enduring consociational (sectarian) system of governance begun under the French Mandate from 1920 onwards (Krijnen \& Fawaz, 2010). Perhaps as a result of this, its positionality is often framed as a multi-cultural confluence in a geopolitical context in which Lebanon plays less of a critical role in its own affairs than its neighbours and allies of its various 
social sects. This refers firstly to the major role Syria played in Lebanese internal affairs up until 1990, despite being the economic and structural opposite of Lebanon as a quasi-secular Arab republic with an economic model based on Soviet-influenced command economy principles rather that Lebanon's longstanding laissezfaire economic liberalism and Beirut's trade-port status. Secondly, a more symbiotic relationship flows from the Israel-Palestine conflict, in which Beirut found itself particularly entangled as a major site of coordination for the Palestine Liberation Organization, the Popular Front for the Liberation of Palestine, and other Palestinian militant groups and some 300,000 refugees.

Yet, while Lebanon has typically been a price-taker in these wider developments, it is also because of them that Beirut emerged as the pre-eminent trade port in the region in the mid-twentieth century following the decline of neighbouring Haifa's maritime trade importance. Additionally, major events from the 1950 s to the early 1970s, including the Suez and oil crises, benefited Beirut in removing its competition as an oil and goods port for the region (Huybrechts, 2002).

The civil war also interrupted a certain process of transformation in the decolonisation period from 1943 onwards, on the basis of two masterplans in 1943 and 1963 for Beirut involving French architect and urban planner Michel Écochard. This process foresaw a "Paris of the Middle East," in which the religious and linguistic diversity of Beirut would play out on small squares and streets with open cafés, accentuating the universities and institutions based in the city (and its likeness to the former colonial power). A national law on banking secrecy was the starting point in 1956 for a structural shift to a servicebased economy in Lebanon, firstly in banking (six international banks set up their headquarters In Lebanon immediately upon this development) and alongside the development of a free zone at Beirut's port, and a heightened tourist and office space offer via a construction boom (Corm, 1998).

In the Chehabi period from 1958-1964 this was boosted through the establishment of a raft of public and private institutions, including a central bank, replacing the informality of the first iteration of consociationalism with a focus on aggrandising Beirut's profile as a hub of enterprise and banking in the region. The economic growth that accrued from these interventions was decisively lost in the civil war, which destroyed much of the inner city's built fabric. This growth plan, however, hugely underestimated the population rise that would be precipitated by migration in the wider region before the civil war and resulted in what became known as the "misery belt" around the city, an unchecked rapidly accumulating sprawl of informal housing. The civil war from 1975-1990-itself a complex product of these factors and others among which the Maronite (Christian) sect's dominance of the sectarian governmental system at the expense of the Sunni, Shia, and Druze groups featured prominently-brought huge destruction to Beirut and instigated the city's erstwhile division into East and West Beirut (Fisk, 2001).

The bones of the reconstruction after the civil war can however be seen in these earlier developments in the city, although the scale of post-war transformation could scarcely have been anticipated. This was partly a reflection of the post-1990 environment of footloose monetarism and enthusiastic IMF prescriptions to impose neoliberal "openness" on developing economies throughout the world (particularly those the Cold War had hitherto precluded it from reaching), and partly by design through the inner city transformation plan driven by a public-private body, Solidere, in a mire of clientelism and with a focus on building a property market based on high-end developments in Beirut's city centre (Nasr \& Verdeil, 2008).

\section{Global Cities, Relational Cities}

Beirut's inclusion in the 2020 update of the Globalization and World Cities Research Network index as a "beta+" city, alongside much larger and more economically integrated agglomerations such as Barcelona and Houston and despite the failure of the post-war reconstruction period to reconnect Beirut to regional circuits (Huybrechts, 2002), sits somewhat uneasily alongside its virtual non-inclusion in global production network (GPN) analysis. Beirut can therefore be considered as a case to explore current contentions within the theorisation of global cities (Sigler et al., 2021), and serves as terrain for reflection on the empirical application of relational urbanisation and the relational city as category.

Research on relational cities is a relatively nascent categorical theme in urban geography typified initially by studies of offshore financial centres (or tax havens) which have developed as nodes between the regional and global economic scales under financialised capitalism, extracting extraterritorial gains at odds with their normative geographic scale and playing a geo-economic role based on "borrowed size" (Alonso, 1973; Hesse, 2016). Rooted in the global geography of capitalist flows and with relevance to the shift in production towards GPNs, advanced and professional service industries, and financialisation, the category includes the types of cities and city-states which can hope to achieve relational positionality and the urban formations which emerge from transformation towards this "small-but-global" configuration.

Theoretically grounded in the arguments for a relational view on space (Massey, 2005), its principal conceptual implication for urban studies is that the "container view" of cities as bounded territories in which processes unfold is eschewed for a relational lens which sees cities constituted as "dense bundles of social relations and power infused interactions that are always formed out of entanglements and connections with dynamics at work in other places, and in wider regional, national and transnational arenas" (Hart, 2002, p. 297). 
The relational lens on cities is an important aspect of the debate in postcolonial urban studies about the applicability of urban theory from the Global North in Global South urban contexts, where its methodological import is deployed variously as a means of dismantling constructs such as "global cities" in favour of an "ordinary cities" approach (Robinson, 2006), or seeing cities embedded in a world of relations (Söderström, 2014). This approach has arguably given the relational lens a certain global portability and potential to overcome "comparative gestures" (Robinson, 2011) when applying urban theories to cities in different regional contexts, although its theoretical application is currently couched somewhere between the ubiquitous level of all cities being relationally composed and the specific level of cities being categorically "relational" owing to their geo-economic positionality. At the analytical level, Söderström points to the relevant way of seeing: "[A] relational analysis of cities requires that we abandon abstract conceptions of relations as 'swirls of flows' to consider them as historical products, moored in material forms and generating change through power-mediated processes" (Söderström, 2014, p. 3).

Methodologically and empirically, a relationalcomparative approach to urban comparison (Ward, 2010) has become established and emergent financial hubs such as Doha were considered along with more established tax-haven city-economies such as Panama (Sigler, 2013), and then expanded to more multi-scalar relational comparisons including Singapore, Luxembourg, and Geneva looking particularly at the governance properties of city-states of different kinds endowed with sufficient power to direct public and private development and maintain a legislative environment conducive to global business. This comparative constellation developed the category into a process of relational urbanisation (Wong et al., 2021), which considers the particular histories and geographies alongside the economic, governance, urban, and spatial development strategies employed by cities and city-states to gain relational positionality in global flows and their attendant development patterns (Figure 1).
In situating Beirut in this literature, the purpose is to synthesise both the generalising and specifying logics of these approaches in a complementary way which utilises the explanatory power of relational urbanisation to describe processes of reterritorialisation in a wider range of locales which, while transformed relative to their previous scale and orientation in pursuit of relevance to contemporary flows under global capitalism, are not key nodes in GPNs or have otherwise notable "small but global" characteristics, but nonetheless relationally play some regional connecting or primate city role historically and currently. In addition to a wider empirical applicability of relational urbanisation there may be scope in applying this lens to Beirut to alter the operational definition of relational urbanisation to describe less the outcome of the process in terms of positionality and more in terms of the shape and extent of reterritorialisation engendered by the process. For the category of relational cities, using this definition of relational urbanisation it may be apposite similarly to reorient the operational definition to refer not to all cities or a small subset of global performers, but to those agglomerations where relationality is the principal historical driver of development, as opposed to, e.g., urbanisation around shifting or emerging industries.

\section{Beirut's Relational Urbanisation?}

But what makes this urbanisation specifically relational? How does relational urbanisation specifically manifest and present itself in Beirut? How, and where, do the spaces and flows of Beirut as a relational city emerge, and where are they interlinked?

The argument that Beirut's history is an example of a city principally constituted as a function of its relations, positionality, and its ability to use its introverted consociational governance system to extroverted effect is straightforward beside the argument that its current constellation still exhibits relationality. The unfolding crisis emphasises hitherto the embeddedness and resilience of the Lebanese political system in struggling not to reform itself regardless of the externalities it imposes

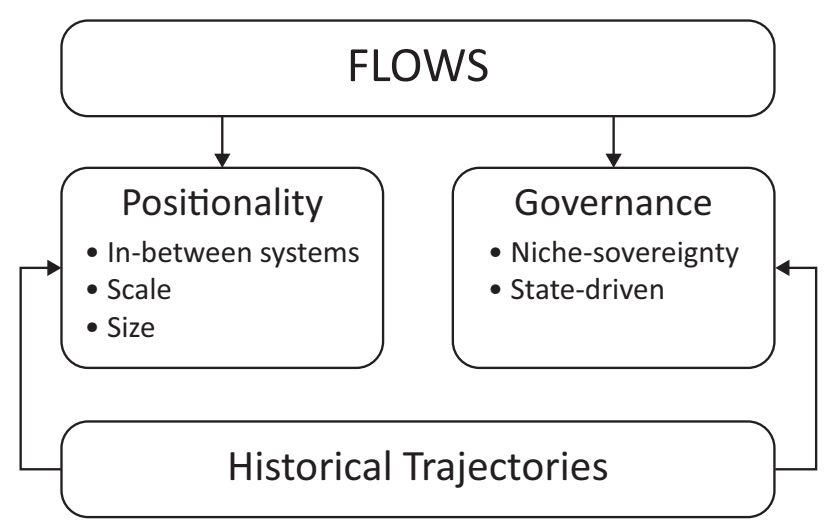

Figure 1. Cities seen through a relational lens. Source: Hesse and Mei-Ling (2020). 
on the population and diaspora (Verdeil, 2018) and the failure of any pretentions towards the beta+ "global city" status given by the Globalization and World Cities Research Network. What was previously a "Switzerland of the Middle East" banking hub became a mere "capital sink" (Krijnen et al., 2017) before succumbing to a financial crisis and hyperinflation since 2019.

But since the argument is that relational urbanisation is about processes more than positionality, and the reterritorialisations and reorientations produced by urban change towards shifting global and regional flows, it is necessary to look beyond the headlines to see relational urbanisation at work. A proposed taxonomy of relational urbanisation in Beirut takes account of the following processes, their locations, and intersections.

\subsection{Commodification of Inner-City Property and Concomitant Suburban Growth Pattern Produced}

Entrepreneurial designs on the post-war redevelopment of Beirut's inner city and suburbs were already wellunderway in the mid-1980s when the neoliberal commodification of urban land and financialisation were sweeping major Western cities. In this sense, the constitution and commissioning of Solidere in 1994 as a private finance initiative to oversee the reconstruction the inner-city in this vein made the contours of the inner-city development clear. An economy which had lost its banking hub role during the war and its ubiquitous maritime significance owing to changes in global logistics and new regional ports, it could be argued that a city reliant on eking out a role as a relational intermediary had no choice but to become magnetised towards the global proliferation of speculative real-estate and the associated financial flows. The early days of the Taif Agreement system required "buy-in" from erstwhile opponents, and the commodification of the ruined inner-city provided a means by which the spoils of peace could be shared out. Since 2007, real estate investments have displaced services as the largest foreign direct investment and expenditure sector in the Lebanese economy, with properties in inner-Beirut representing the lion's share of these (Figure 2). Such a steep reorientation towards a rentier model has in the last 15 years rendered the national economy mostly unproductive and subject to the fluctuations of the global property market, as the already dwindling sectors of agriculture and industry continue their decline.

The outward use of rent-gap creation in inner Beirut as a means of depopulating areas of the inner city has been well documented in the literature (Fawaz et al., 2018; Krijnen, 2018; Krijnen \& De Beukelaer, 2015), but its concomitant effect of shifting Beiruti workers to more affordable suburban towns and districts is either only implied in the literature through indicators such as increased car-use, or considered historically. As gentrification of the edge of the inner city continued, this put more pressure on the suburbs and their lacklustre infrastructure (Basbous, 2021). But the clearing-out of inner-city populations towards attractiveness towards global financial flows through gentrification and large-scale urban redevelopment projects and a concomitant pressure in suburban areas has been recognised as a feature in relational cities (Hesse \& Rafferty, 2020). The "unplanned" growth often ascribed to Beirut's suburbs is perhaps more accurately referred to as "informally planned," given that the hybrid sovereignties (Fregonese, 2012) which are de facto conducting planning policy in Beirut retain control over development in these areas (Fawaz, 2009).
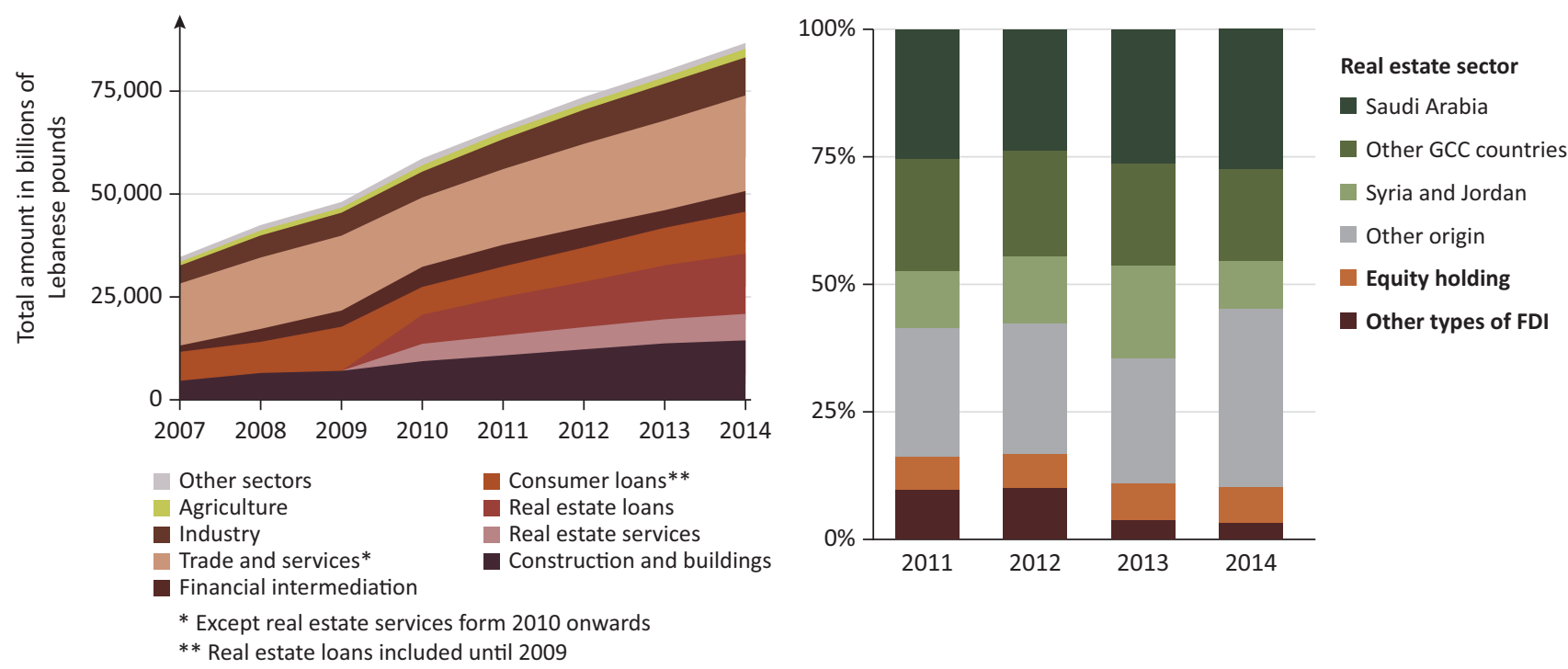

Figure 2. Evolution of the sectorial distribution of bank credit from 2007 to 2014 (left); origin of foreign investments in Lebanon per sector (right). Source: Verdeil et al. (2019, pp. 53, 55). 


\subsection{An Introverted Governance System With an Extroverted Economic Strategy}

Introverted governance alongside an extroverted economic orientation has been identified as an aspect of the strategies underpinning relational urbanisation (Hesse \& Rafferty, 2020), and in Beirut the lack of a strong urban governance and centralised power of the national system produces a familiar pattern to city-state formations able to use their "niche sovereignty" (Hesse, 2016) to direct development through and around pliant governance structures. A key example of this is the establishment of Solidere, using state power to create a hybrid development organisation and make legislative changes to laws on land ownership and rents to allow it to operate (Krijnen, 2018).

On the other hand, Lebanon's international orientation is avowedly extroverted, servicing and using its diaspora and connections with international economies through an extensive diplomatic network belying the country's size (Figure 3). The retention of regionally significant NGOs, international institutions, and INGOs with competing methods and strategies (Hamieh \& Mac Ginty, 2010), despite an overall loss in regional economic significance as well as the maintenance of several internationally-oriented universities since the 19th century, demonstrates the territorialized aspect of this extroversion.

\subsection{Contradictions in Infrastructural Development and Labour Profile}

Relating to material flows, Lebanon's severe import/ export imbalance finds only one major conduit-Beirut port, which has waned from being a main locale of relationality to critical global flows to being an essential lifeline for the supply of Lebanon's domestic market even after its destruction in the August 2020 blast. While the port stepped to this second-order purpose since the civil war, Beirut international airport's capacity increased six-fold as part of the reconstruction boosterism under Rafik Hariri, who gives it its name. Water and energy infrastructure remain woefully underdeveloped stateowned utilities in Lebanon, particularly for the areas of population growth in the suburbs and refugee camps, where the black market is a ubiquitous supplier of these essentials (Verdeil, 2018).

Whereas the transformation towards global city is typically marked with an attraction of expert expats and the sourcing of a commensurate lower-waged labour to service the changed consumer needs of the new population, Beirut's labour profile remains peculiarly relational even as a mere "capital sink" (Krijnen et al., 2017) with large numbers of multilingual, highly-educated graduates from the city's cluster of prominent universities typically seeking roles in the global and regional informational and financial economy which connect the city to

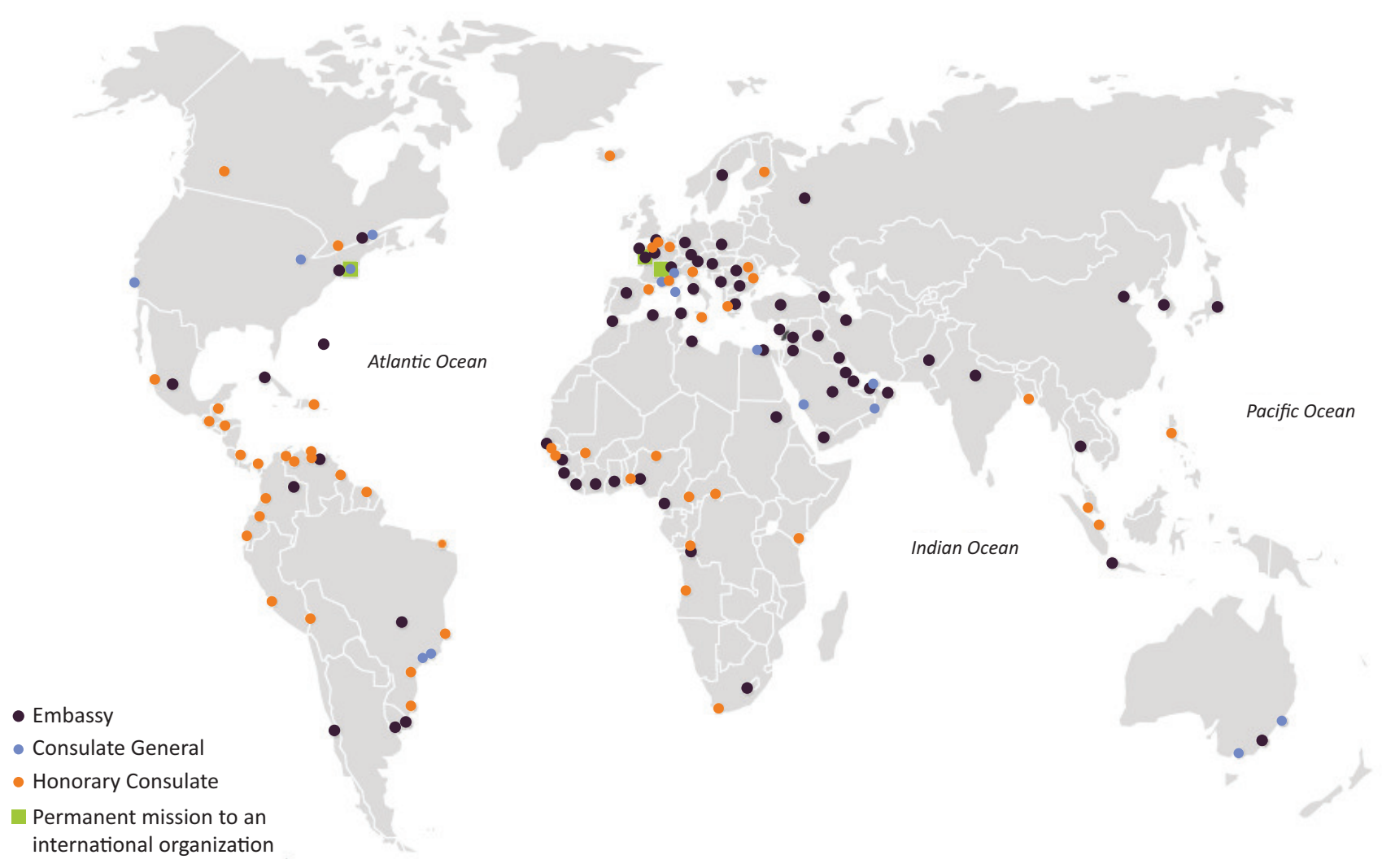

Figure 3. The Lebanese diplomatic network at the beginning of the 2000s. Source: Verdeil et al. (2019, p. 43). 
international circuits, and feeding the "financial fix" of a financialised version of a diaspora strategy. In-flows of domestic workers from Asia and Africa on the other hand are subject to poor conditions and clamping down on trade union activity (International Labour Organization, 2016), while the established trade unions in Lebanon enjoy some qualified positionality in the national political picture (Baumann, 2016).

Thus, the manifestations, interconnections, and contradictions of relational urbanisation can be observed through qualitative engagement with the relevant institutions, economic and social actors, and individuals and groups which operate in the city and maintain its problematic relational connection to international flows.

\section{Conclusion}

This exploration of Beirut's urbanisation in the light of debates on relational space therefore sites the city and national footprint of urbanisation as a case of relational urbanisation in principle, not by degree. Beirut is an example of a relational city by virtue of its urban constitution as a connector of systems of flows between regional, national, and global scales. While all cities are to one degree or another "relational," cities with this profile are primarily relational in their composition and reproduction of urban space through their internal governance dynamics and economic profile. Analytically, the relational lens on the production of urban space is a way of unravelling the threads of this complex case of relational urbanisation, linking hitherto discrete strands of critical urban scholarship on the city. For studies of relational urbanisation more widely, this study points to a shift in relevance of the reterritorialisation that flows from the urbanisation process over that of the comparative economic positionality achieved by other "small-but-global" relational cities, thereby increasing the relevance of this concept a wider range of possible empirical urban sites of inquiry. In Beirut, the particular blueprint underpinning this relational urban case is experiencing an organic crisis and is thus potentially open to alternative geographies.

But such alternatives do not arrive out of nowhere. The revolutionary space opened up by the October 2019 protests, while still tentative in nature, demonstrated the willingness of Lebanese citizens to discern pathways out of crisis on the major political questions, many of which are essentially urban in nature, with or without the Lebanese ruling class. While shocks and crises have intervened to contain the development of protests into revolutionary demands in the meantime, the idea that the Lebanese ruling class will be able to return to a previous state of affairs seems remote. It is thus in the "evental wake" (Badiou, 2007) of the October 2019 protests that paths towards alternatives can be discerned and advanced by the various actors that constitute Lebanon's political ecosystem.

Such possible alternatives would make for an exciting future empirical exploration of what the alternative to relational urbanisation in Beirut might involve, including but not limited to the following areas: (a) recovery of relationality over positionality (i.e., a rebalancing of the focus of flows from financial to material and intellectual), (b) urban planning as a catalyst for developing infrastructure and a productive economy, (c) the development of an urban economy beyond real-estate, and (d) a local-national spatial politics. An expansion of the discourse on these areas would be a welcome departure from the normative assumptions underpinning framings of "resilience" which are frequently used to discuss the emergence from the present compound crises affecting the city and state. Whereas the critical literature on urban resilience has addressed its role in advancing policy narratives of certainty (Smirnova et al., 2021), a relational lens on processes of urbanisation offers a more reflexive methodology of discerning possible alternatives without reifying the present governance paradigm of the Lebanese ruling class.

\section{Conflict of Interests}

The author declares no conflict of interests.

\section{References}

Akar, H. B. (2018). For the war yet to come: Planning Beirut's frontiers. Stanford University Press.

Alonso, W. (1973). Urban zero population growth. Daedalus, 102(4), 191-206.

Badiou, A. (2007). Being and event. A\&C Black.

Basbous, M. (2021). From the rubble of Beirut. Architectural Review. https://www.architectural-review. com/essays/city-portraits/from-the-rubble-of-beirut

Baumann, H. (2016). Social protest and the political economy of sectarianism in Lebanon. Global Discourse, 6(4), 634-649.

Corm, G. (1998). Reconstructing Lebanon's economy. In N. Shafik (Ed.), Economic challenges facing Middle Eastern and North African countries (pp. 116-135). Palgrave Macmillan.

Fawaz, M. (2009). Neoliberal urbanity and the right to the city: A view from Beirut's periphery. Development and Change, 40(5), 827-852.

Fawaz, M. (2014). The politics of property in planning: Hezbollah's reconstruction of Haret Hreik (Beirut, Lebanon) as case study. International Journal of Urban and Regional Research, 38(3), 922-934.

Fawaz, M., Krijnen, M., \& El Samad, D. (2018). A property framework for understanding gentrification: Ownership patterns and the transformations of Mar Mikhael, Beirut. City, 22(3), 358-374.

Fisk, R. (2001). Pity the nation: Lebanon at war. Oxford University Press.

Fregonese, S. (2012). Beyond the "weak state': Hybrid sovereignties in Beirut. Environment and Planning D: Society and Space, 30(4), 655-674.

Gramsci, A. (1971). Selections from the prison notebooks. 
Lawrence \& Wishart.

Hamieh, C. S., \& Mac Ginty, R. (2010). A very political reconstruction: Governance and reconstruction in Lebanon after the 2006 war. Disasters, 34(s1), S103-S123.

Hanssen, J. (2005). Fin de siècle Beirut: The making of an Ottoman provincial capital. Oxford University Press.

Hart, G. (2002). Disabling globalization: Places of power in post-Apartheid South Africa. University of California Press.

Hesse, M. (2016). On borrowed size, flawed urbanisation and emerging enclave spaces: The exceptional urbanism of Luxembourg, Luxembourg. European Urban and Regional Studies, 23(4), 612-627.

Hesse, M., \& Mei-Ling, C. (2020). Cities seen through a relational lens. Geographische Zeitschrift, 108(2), 74-98.

Hesse, M., \& Rafferty, M. (2020). Relational cities disrupted: Reflections on the particular geographies of COVID-19 for small but global urbanisation in Dublin, Ireland, and Luxembourg City, Luxembourg. Tijdschrift voor economische en sociale geografie, 111(3), 451-464.

Huybrechts, E. (2002). Beirut: Building regional circuits. In S. Sassen (Ed.), Global networks, linked cities (pp. 237-246). Routledge.

International Labour Organization. (2016). Building bargaining power: How domestic workers in Lebanon made a courageous step to form a union. https:// www.ilo.org/wcmsp5/groups/public/---arabstates/--ro-beirut/documents/publication/wcms_ 492341.pdf

Jansen, M. (2020, September 1). Lebanese philanthropist Lady Cochrane (98) dies of blast injuries. The Irish Times. https://www.irishtimes.com/news/ world/middle-east/lebanese-philanthropist-ladycochrane-98-dies-of-blast-injuries-1.4344057

Jidejian, N. (1973). Beirut through the ages. Dar el-Mashreq.

Kassir, S. (2011). Beirut. University of California Press.

Khalaf, S., \& Kongstad, P. (1973). Hamra of Beirut: A case of rapid urbanization. Brill.

Khuri, F. (1975). From village to suburb: Order and change in greater Beirut. University of Chicago Press.

Koch, N. (2018). The geopolitics of spectacle: Space, synecdoche, and the new capitals of Asia. Cornell University Press.

Krijnen, M. (2016). The urban transformation of Beirut: An investigation into the movement of capital [Doctoral dissertation, Ghent University). https://biblio. ugent.be/publication/7245765

Krijnen, M. (2018). Beirut and the creation of the rent gap. Urban Geography, 39(7), 1041-1059.

Krijnen, M., Bassens, D., \& Van Meeteren, M. (2017). Manning circuits of value: Lebanese professionals and expatriate world-city formation in Beirut. Environment and Planning A: Economy and Space, 49(12), 2878-2896.
Krijnen, M., \& De Beukelaer, C. (2015). Capital, state and conflict: The various drivers of diverse gentrification processes in Beirut, Lebanon. In L. Lees, H. B. Shin, \& E. López Morales (Eds.), Global gentrifications: Uneven development and displacement ( $\mathrm{pp}$. 285-309). Policy Press.

Krijnen, M., \& Fawaz, M. (2010). Exception as the rule: High-end developments in neoliberal Beirut. Built Environment, 36(2), 245-259.

Massey, D. (2005). For space. SAGE.

Naeff, J. (2017). Precarious imaginaries of Beirut: A city's suspended now. Springer.

Nasr, J., \& Verdeil, E. (2008). The reconstructions of Beirut. In The City in the Islamic World (2 vols.) (pp. 1121-1148). Brill.

Robinson, J. (2006). Ordinary cities: Between modernity and development. Routledge.

Robinson, J. (2011). Cities in a world of cities: The comparative gesture. International Journal of Urban and Regional Research, 35(1), 1-23.

Salloukh, B. F. (2019). Taif and the Lebanese state: The political economy of a very sectarian public sector. Nationalism and Ethnic Politics, 25(1), 43-60.

Sigler, T. J. (2013). Relational cities: Doha, Panama City, and Dubai as 21st century entrepôts. Urban Geography, 34(5), 612-633.

Sigler, T., Martinus, K., lacopini, I., Derudder, B., \& Loginova, J. (2021). The structural architecture of international industry networks in the global economy. Plos one, 16(8), Article e0255450.

Smirnova, V., Lawrence, J. L., \& Bohland, J. (2021). The critical turn of resilience: Mapping thematic communities and modes of critical scholarship. The Geographical Journal, 187(1), 16-27.

Smith, N. (2005). The new urban frontier: Gentrification and the revanchist city. Routledge.

Söderström, O. (2014). Cities in relations: Trajectories of urban development in Hanoi and Ouagadougou. Wiley.

Tabet, J. (1991). La ville imparfaite. Le concept de centralité urbaine dans les projets d'aménagement et de reconstruction de Beyrouth [The imperfect city. The concept of urban centrality in development and reconstruction projects in Beirut]. MOM Éditions, 5(1), 85-120.

The Beirut Banyan. (2019, October 16). Ep. 14 (Audio): Family Inheritance with Roderick Sursock [Video]. https://www.youtube.com/watch?v=VNkQaNgHwC $c \& t=12 s$

The Economist. (2021, September 2). What makes a failed state? The Economist. https://www.economist. com/the-economist-explains/2021/09/02/whatmakes-a-failed-state

Verdeil, É. (2005). Plans for an unplanned city: Beirut (1950-2000). Worldview.

Verdeil, É. (2018). Infrastructure crises in Beirut and the struggle to (not) reform the Lebanese State. Arab Studies Journal, 16(1), 84-112. 
Verdeil, É., Faour, G., \& Hamzé, M. (2019). Atlas of Lebanon: New challenges. Presses de l'Ifpo.

Verdeil, É., \& Nasr, J. (2017). Planning histories in the Arab world. In C. Hein (Ed.), The Routledge handbook of planning history (pp. 273-287). Routledge.

Ward, K. (2010). Towards a relational comparative approach to the study of cities. Progress in Human Geography, 34(4), 471-487.

Wong, C., Hesse, M., \& Sigler, T. J. (2021). City-states in relational urbanization: The case of Luxembourg and
Singapore. Urban Geography.

Yassin, N. (2012). Beirut. Cities, 29(1), 64-73.

Zaarour, R., \& Voiron-Canicio, C. (2020). Les transformations morphologiques du tissu bâti de Beyrouth depuis 1950. Analyse morpho-dynamique à échelle fine [Morphological transformations of the urban fabric of Beirut since 1950. A fine scale morphodynamic analysis]. Méditerranée: Revue géographique des pays méditerranéens/Journal of Mediterranean Geography, 2020(131).

\section{About the Author}

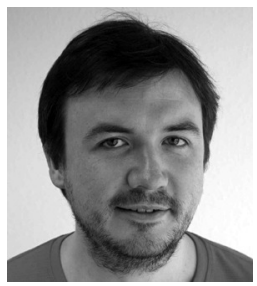

Michael Rafferty is a PhD candidate in the Department of Geography and Spatial Planning at the University of Luxembourg, supervised by Prof Markus Hesse. He holds an MA in human geography from Queen's University Belfast. 